\title{
From Separated Laws and Directives to a Unique Regulatory Issue in Europe about the Synergic and Conflicting Use of Subsurface to Produce Low Carbon Energy
}

\author{
Fedora Quattrocchi
}

INGV: Istituto Nazionale Geofisica e Vulcanologia, Via di Vigna Murata 605, Roma, Italy

Corresponding Author Email: fedora.quattrocchi@ingv.it

https://doi.org/10.18280/ti-ijes.632-436

Received: 19 January 2019

Accepted: 23 April 2019

\section{Keywords:}

planning of: Underground energy potential, natural gas storage, geothermal energy, $\mathrm{CO}_{2}$, natural gas storage, nuclear waste management, water waste management, energy storage

\begin{abstract}
At the European Parliament is urgent need to merge a "Unified European Directive for the use of subsurface and lands to produce energy/heat/resources", especially creating an "unified permit exploration", because energy-heat technologies for the subsurface are multiplied and increasingly interconnected: i) the same crustal block can now be used both at several layers and in several geologic strata, for example combining geothermal energy with $\mathrm{CO}_{2}$ storage: ii) gas production with subsequent or simultaneous natural gas storage $\left(\mathrm{CH}_{4}\right)$ both conventional and unconventional $(\mathrm{CBM}=\mathrm{Coal}$ Bed Methane, as well as shale/oil gas); iii) injection of fluids during the production geothermal energy; iv) energy storage in the upper layers and maybe - below - a reservoir of Enhanced Geothermal System (EGS) to reinject fluids: the $\mathrm{CO}_{2}$ can be stored in coal beds at shallower levels or by deeper Enhanced Oil Recovery $\left(\mathrm{EOR}-\mathrm{CO}_{2}\right)$; v) shale gas can be extracted with aqueous fluids, from other layers, as scrap unconventional production in more desert areas (i.e. where induced/triggered seismicity has less risk). Water waste management is to be included too, as well as regulatory framework for abandoned-orphan wells.

The vision of the paper - here only partially discussed due to the few pages available, moves and is driven by the multi-faced Italian regulatory framework, which is very complete/complex, despite divided in - at least - 5 different laws, not jointed in any manner up to date each-other.

In particular, a dozen Italian laws would be merged in a single law/directive, "Unified European Directive for the use of subsurface and lands to produce energy/heat/resources", that makes faster the authorization process for a "unified permit exploration" both at Ministry of Economic Development and at Environmental Impact Assessment (VIA-VAS) procedures. As an example, the pre-existing laws, including geothermal energy legislation - opening the market to little enterprises too - that only recently (2010) has been renewed, is already obsolete, both in the light of public acceptance issues (very useful should be the use of 3D printer scaled underground vision!), and in the light of new technologies using the underground 3D space to produce energy-heat, coming from overseas, to be customized for each country in the Strategic Energy Planning (SEN).
\end{abstract}

\section{INTRODUCTION}

The most urgent problem of Humanity is to produce a large quantity of energy ( 9 billion people almost!) by the minimum GreenHouse Gases (GHGs) production, in the minimum space and time as possible, using scenarios not so far from the real technological and financial results [1].

A century of energy engineering was dedicated to the development of increasingly large centralized plants primarily power stations, refineries, steel industries and cement plants, very GHGs producing - made with enormous infrastructural efforts - in order to bring the products [ $\mathrm{MWh}_{\mathrm{e}}$ ], $\left[\mathrm{MWh}_{\mathrm{t}}\right]$ as close as possible to consumption points and into our homes. Oil tankers, oil pipelines, power lines, large dams, capillary service stations located in each country, cables that penetrate the walls of our homes, extreme outcrops of an uninterrupted thread coming from hundreds of kilometers away.

And after what seemed to be the state of the art of the energy distribution process until yesterday, we are witnessing the first steps of what will presumably be the complete deconstruction of the system, thanks to self-production by small, widespread systems that draw the energy from the sun, from the wind (onwards RESs, Renewable Energy Solutions, in Italy: FERs) and from the heat of the underground, storing it for use that covers the arc of the whole day through adequate storage systems.

All this has been done and is still ongoing, minimized mostly where the GHGs production from fossil fuels power plants is maximum - the rapid technologies capable of storing the GHGs from the above-mentioned enormous plants, in the subsurface by geological storage $\left(\mathrm{CCS}=\mathrm{CO}_{2}\right.$ Capture \& Storage, see www.globalCCSInstitute.org). The necessary incentives have not been given to CCS till now, as it was given to the RESs and to Energy Efficiency remediation, as "dictat" in all the European SET PLAN ENERGY groups, country by country.

This process occurred mainly where private foundations often managed by policymakers in enormous conflicts of interest - arisen wherever for private gain of these people, and 
in particular in Italy, where the incentives to the RESs were given to the installations of wind/solar devices and not to the final produced MWh! What's wrong! A lot of installationpeople was created, no-running devices often built up and not so much low carbon MWh produced! Not all the GHGsControl Technologies were therefore awarded by incentives at the same time and in the same manner, creating a big damage and an overall European economic crisis. In Italy the crisis is maximum because maximum was the speculation above mentioned.

Hence the need to review and rework the concept of "Smart Cities and Communities" towards "Smart ancient cities-landssubsurface planning", in the framework both of future Horizon 2020 calls planning and of industry/policymakers strategic plan. Hence, moreover, now it arises the need for a unique carbon tax as a new worldwide coin, and a single "Unified European Directive for the use of subsurface and lands to produce energy/heat/resources", that starts strategic planning reasoning from each crustal block (subsurface + lands at surface) to exploit in new infrastructures, where to implement the various technologies in different depths [2-3], without none prevailing each-other, both taking into account: i) the maximum producible energy with minimum GHGs and environmental impact, ii) the priority of research as a function of "energy density" normalized to lower GHGs iii) the development ethical behavior on this topic and in the granting of political incentives without conflict of interest toward a new techno-political class for Europe [4-7].

In order to not prematurely dismantle the large electrical systems of major historic operators (in Italy ENEL, but also Siemens, Alstom Power, RWE, Battelle in the USA, and whatever else), we must try every tool to keep them alive, by maximum possible cut of GHGs: this can be achieved by RESs and Energy Efficiency as already known, but strongly accompanied by the CCS technologies to be diffused widely in Cina, India, etc..., during this "bridge period" passing to a de-carbon Earth Planet, as soon as possible. In any case, at this late stage of catastrophic climate change situation where, GHGs are escaping a lot and a lot from the big emissive plants - as for an emorragy stopped by a simple "band-aid" (RESs and Energy Efficiency tools !), without CCS jointed to coal plants and without the natural gas storage sites, to minimize the coal use, climate change will be fast and irreversible. Namely no solution to the irreversible/feed-backed fast climate change exist without giving soon incentives both to CCS for big plants, and to the passage from coal to natural gas plants, where it is possible, leaving in any case some cleancoal technology plant with CCS running again, because coal is a more available and widespread fossil fuel worldwide. In Italy, at least 20 natural gas storage sites are located, being a natural "gas hub" for Europe, therefore in these few pages we start the discussion from the natural gas storage sites here, toward the "Unified European Directive for the use of subsurface and lands to produce energy/heat/resources".

\section{METHODS}

This limited preliminary paper moves only for one branch of the proposed EU Directive, taking in consideration the new paradigms of main different uses of subsurface: to produce energy, to store fluids/MW for energy storage, to perform safety water-waste management, to perform safety nuclear waste management, etc. reviewing the main critical aspects of the different technologies, towards a new regulatory reasoning and reworking pre-existing laws, namely to build up a "Unified European Directive for the use of subsurface and lands to produce energy/heat/resources".

Underground subsurface should be conceived as a unique rationally planned "space", to produce low-carbon fuels, resources and goods, including potable groundwater.

This new EU Directive is suggested and driven here by the Italian regulatory framework, which is very complete, despite divided at least in 5-6 different laws, not jointed in any manner up to date, because written, stated and officially published in very different periods of the political Italian life, in the last decades, in the frame of the technological evolution. The method to write the Directive tends to maximize the priority for the critical nuclear waste disposal as primary destination to be evaluated for underground and land, due to the complex situation rendering suitable and sound a site for nuclear waste destination (mostly for the HLW management). Therefore, considering that in any country at least one nuclear waste disposal i.e., Nuclear Technological Park of SOGIN, as proposed is necessary, its choice should have priority and be mandatory, before the consideration of other energy-strategic uses for underground space and land.

In particular, a dozen Italian laws are concerted and summarized in a single law proposal - better - that keep rationality and speeds up the process in the Ministry of Economic Development and Environmental Impact Assessment (VIA-VAS) for operators, including geothermal legislation (that only recently -2010- has been renewed, but it is already obsolete, in the light of new technologies of the use of the subsurface coming from overseas): i) an ancestral D.P.R of 09-04-1959 on "mines and quarries", that today is absolutely obsolete for the purposes of new "mixed" production perspectives, for example Coal Bed Methane's unconventional natural gas (CBM, also known as $\mathrm{CSG}=$ Coal Seam Gas as the so-called "non-conventional gas" chain) and / or energy storage; ii) Decree Law 625 of November 1996 implementing European Directive 94/22, concerning the exercise of authorizations for exploration, research and cultivation of hydrocarbons, which in Art.13 defines rules on the conferral and operation of concessions for cultivation and storage of natural gas (why not to $\mathrm{CO}_{2}$, for example ?) iii) the DL 64/2000 on natural gas storage which followed: iv) the Law 170 of 26-04-1974 on the same subject (this law was a prime example of "merging" of joint use of subsurface, between storage of natural gas and former hydrocarbon exploitation reservoir); v) the Law 239 of 2004, that does not provide for a subsurface site a "change of intended use", while it is consubstantial of the productive underground, to be over time used for different uses, perhaps before producing hydrocarbons, then storing natural gas and then maybe $\mathrm{CO}_{2}$ or geothermal storage and hot water for example; vi) Presidential Decree 197 of 29-11-2009 which assigns UNIMIG of all storage facilities, except those on nuclear waste, even though they are potentially "geological"; vii) the Law 99 of 23-072009, "Provisions for the development and internationalization of companies, as well as energy"; viii) the Ministerial Decree 26-04-2010 also containing "standard regulations for exploration and research permits and for concessions for the cultivation of liquid and gaseous hydrocarbons on the mainland, in the territorial sea and on the continental shelf"; ix) the application in Italy of the new European Directive 31/2009 on geological storage of $\mathrm{CO}_{2}$, complied with in Italy as D.L. 162/2011, despite it does not 
provide that the study of underground productive lands can then lead the investors (increasingly rare and discouraged) to carry out jointed projects, i.e., with geothermal energy or, in place of natural gas storage, if $\mathrm{CO}_{2}$ storage is/become unsound or not convenient and $\mathrm{x}$ ) others minor laws and EUdirective achievement laws.

The legislation on geothermal D.L. 22 of 22/02/2010 has highlighted - in turn - all the possible limitations of the actual rooting and implantation of operational projects and experimentation-test sites, also of electrical production, up to the great depths with or without the use of circulating fluids (binary cycle, Hot Dry Rocks, etc. ...). Only by reworking this regulatory framework, as a whole, the new paradigms of natural gas storage could be well and soundly managed. Speculative Geothermal Energy framework should be avoided (see Italian case histories recently, with highlighted conflicts of interest and management failures, [4-5]). Moreover, in this current legislative framework, specific legislation on the research of raw materials in depth (metals, Rare Earths REESs, etc. ... for bacteries) is completely lacking.

\section{RESULTS AND DISCUSSION}

Herewith are discussed only part of the data and laws in the framework of the building new "Unified European Directive for the use of subsurface to produce low carbon energy and heat", as a consequence of the limited pages imposed for the paper, giving an exemplificative step.

\subsection{Natural gas storage example}

The main problems inherent in the storage of natural gas (mainly methane, $\mathrm{CH}_{4}$ ) analyzed to be included in the new "Unified European Directive for the use of subsurface and lands to produce energy/heat/resources" are: capacity (volumes), gas containment as main fair of the citizens also in prairies, where gas storage $\left(\mathrm{CO}_{2}, \mathrm{CH}_{4}\right)$ or geothermal prone areas are located [8-9], mostly if associated to strong earthquakes [10-17] and shallow fluid preservation (safety), geomechanical-induced/triggered seismicity or weak caprock [18-21] safety and public awareness/public acceptance, by a correct and transparent communication. Induced hazards could be produced as $\mathrm{CO}_{2}$ degassing, radon indoor and enhanced radioactivity in aquifers, being ${ }^{222} \mathrm{Rn}$ a natural gas released from the rock matrix during stress-related episodes or activated faults over the $\mathrm{CO}_{2} / \mathrm{CH}_{4} /$ radon natural background $[22,23,24]$

We refer to the papers [2-3] mainly, which are also published to calculate the "energetic density" [MWh/hectars/year], normalized to the minimum GHGs emissions, for all technologies, among which is exploited/ stored natural gas, located in the single-out studied regions.

The "over-pressurization" of the pre-existing natural gas storage, when being not available new sites (not accepted by public typically $[4-6,10]$, is the recent solution exploited in Italy or elsewhere. Some initiatives as the "Collegato Ambientale-Vaccari-PD" 2015", which render mandatory over the entire country the exclusion of "saline aquifers" for gas storage sites, should be discharged, as "populistic" political initiative (see the article on Il Sole 24Ore, May, 24, 2015, signed by Fedora Quattrocchi). In France almost allnatural gas storage are "saline aquifers" however!
In particular, in Italy there is the "MINISTERIAL DECREE 31 JANUARY 2011" called "Acceptance of the development plan of new storage capacities", starting from: i) the DL $23 / 06 / 2000$, N. 164, dealing with "Implementation of the directive N. 98/30 / CE, on common rules for the internal market of natural gas, in accordance with Article 41 of Law No. 144 of 17 May 1999"; ii) the DL 13/08/2010, N. 130, dealing with "Measures for greater competitiveness in the natural gas market and transfer of the resulting benefits to final customers". In particular, here are mentioned:

-the Art. 30, commas 6 e 7, of the DL 23/07/2009, N .99" and from Art. 5, commas 1, which foreseen the: a) the entity that adheres to the implementation of the measures regulated therein assumes a binding commitment, also in terms of performance characteristics and implementation times, to develop new natural gas storage infrastructures or to upgrade existing ones; b) the natural gas storage infrastructure referred to, in point a) above, are selected from the infrastructural development initiatives referred to in Article 4, paragraphs I and 3 of the Decree, so as to make new natural gas storage capacity available as a whole. for a volume of 4 billion cubic meters; c) the commitment referred to in point a) above may be fulfilled through the stipulation of specific contracts: 1 . with storage companies controlling or controlled by the same parent company, on which the responsibility for the timely realization of the infrastructural capabilities commitment and the related obligations will be directly affected; 2 . with storage companies other than those of point 1 and prior definition, in the appropriate contracts, of cases of non-compliance and of adequate forms of guarantee for the entities involved; the Art. 5, commas 3 of the D.L. that provides that the subject who undertakes the binding commitment to develop new natural gas storage infrastructure or to upgrade existing ones, must transmit to the Ministry of Economic Development (in the following Ministry MISE), to the Italian Competition Authority, in the following Authority guarantor, and to the Authority for Electricity and Gas, in the following Regulatory Authority, by September, 1, 2010 of each year a plan, or an update of the existing plan, for the realization of the new storage capacity by selecting the infrastructures referred to in Article 4, paragraphs 1 and 3 of the Legislative Decree including the time and cost of implementation;

The new law of 2011 is aimed at developing new storage capacity according to criteria of effectiveness, speed and efficiency and, except in cases of unsurpassed technical impediments, is implemented no later than 5 years from the date of the measures. Furthermore, after consultation with the Regulatory Authority, the above plan is accepted, as well as the related updates, without prejudice to the obligation for the persons who realize the storage infrastructures to request the authorizations necessary for the construction of the infrastructures and, where necessary, the related changes in the work programs of the storage concessions concerned.

In accepting the aforementioned plan, projects that are characterized by lower costs and shorter production times are preferentially taken into account. The Eni Spa letter, protocol N. 163 of September, 1, 2010, transmitted to the Ministry, the regulatory Authority and the Guarantor Authority a plan proposal for the construction of new gas storage capacity for over 4000 million cubic meters. The letter from the Directorate General for Security of Supply and Energy Infrastructures of the Ministry of October, 6, 2010 was then sent to Eni Spa and, for information, to Stogit Spa, the Regulatory Authority as well as to the Energy and Management Department general for 
the ministry and energy resources of the Ministry with which some clarifications have been requested, also in order to take into account the observations made by the Regulatory Authority. The Deliberation $15 / 12 / 2010$ of the PAS Regulation Authority 34/10 was followed, containing "Issue of an opinion to the Ministry of Economic Development pursuant to Article 5, paragraph 4 of the Legislative Decree of August, 13, 2010, No. 130 ", with which the favorable opinion was formulated regarding the proposed plan presented by Eni Spa, albeit with the request for further supplementary information regarding the projects included in the same plan. The letter dated January, 20, 2011 from the Ministry for Energy Minerals and Energy Directorate General sent to the Directorate General for Security of Supply and Energy Infrastructures, to the Regulatory Authority, Stogit Spa and Eni Spa, reports that Stogit Spa, for some projects included in the plan, will have to submit to the Offices of the Directorate General for Mineral Resources and Energy (UNMIG of Ministry MISE), the request for approval of the program of works in concession and that these projects will have to be subjected to technical feasibility checks, as well as to verification of "environmental compatibility" from part of the Ministry of the environment (Commissione VIA-VAS), of the protection of the territory and of the sea, the regional agreement and the procedure referred to in the Legislative Decree of August, 17, 1999, N. 334 and subsequent amendments and additions; the plan presented, with the additions and the information subsequently received, includes projects to be implemented, in large part, by "overpressuring" operation of already operative storage fields that, therefore, are characterized by lower costs and implementation times, but also by the need for adequate feasibility checks, especially on two critical points and very sensitive for public acceptance: i) studies on the possible fluids driven induced seismicity (e.g. $[18-19,21])$ to be performed by a large group people and not only by few researchers, often selected "top to down" from pro-tempore heads of Public Research Institutions or Universities, and ii) studies on the so-called Natural Gas Hazard, or the leaks of natural gas up to the surface, i.e., long tectonic discontinuities and fracturing fields, as already highlighted in Italy (e.g. literature below, [8-17]). The "transparency" and "inclusion" rules inside the research centers, have been recently un-attended in Italy (a lot of newspaper articles were published about it), dropping down the "public acceptance" of natural gas sites, where "overpressuring" should be performed. In turn, in other countries, as Canada, a good management of surface monitoring avoid these kind of problems [25-26]. For example, it was recently highlight that some Agreements among MISE Ministry and some Public Research Institutions were not transparent and not reworked by large teams of full experts, as due and expected by the public opinion.

Given that above, all is more difficult for the feasibility of one or more natural gas "overpressuring" projects; and it involves delays for infrastructures, due to the unacceptance of the not transparent and not widely accepted Guide Lines, pursuant to Article 5, paragraphs 3 and 4, of the Legislative Decree, an update of the plan and its further acceptance by Decree of the Minister of Economic Development, after having heard the Regulatory Authority, the Decree of 2011 decrees with Article 1 "Acceptance of the plan to develop new natural gas storage capacity", for 4060 million cubic meters, proposed by Eni Spa, with letter N. 163 of 01/09/2010, in compliance with the provisions of article 5 , paragraph 3 , of the
Legislative Decree, and subsequently integrated through the aforementioned communications of Eni Spa and Stogit Spa no later than 1 September 2015 (still not definitive in the operative exploitation). Art. 2 of the Decree Law of 2011"Supervision and monitoring of the development of the new storage capacity", required that the Guarantor Authority should monitor compliance with the date of September, 2015 as the deadline for the completion of the overall development of the new storage capacity, but in turn it is not yet completed, namely it is not following the complete safety criteria and geoethical behavior of some research/control actors in this framework.

It was foreseen by the 2011 D.L. that is discussed any eventual issue that may cause a delay in the entry into service of the new gas storage capacity and the actions planned for its timely resolution are reported to the Ministry MISE (Economic Development): these concern today public acceptance and public awareness of the new natural gas storage capacity under the "overpressuring" regime: the delay will be overcome only taking out definitively from this monitoring/permits procedures, some research/university manager - often politically driven - which did not allow: i) a good and ethical-transparent, namely co-active and widely accepted management of Agreements among research institutions/agencies, Ministry and Regions on gas storage (the same is valid for hydrocarbons /geothermal productions too, including water waste management) and ii) a full use of Directors of research/Directors Technologies, known being with competence and geo-ethics on the field, we could have a proper "public acceptance". Otherwise a big damage to the country is ongoing: manifestations of the citizens are right.

The importance of natural gas storage is amplified by the fact that some European countries such as Italy are desired as South-European gas "HUB": with the doubling of the North Stream gas pipeline - which Gazprom has designed in alliance with German, French companies, Austrian and British, but not Italian, there still seems to be the risk - remote - of countering the aspiration to transform the peninsula into the aforementioned South-European HUB of natural gas. On the other hand, it is no longer possible to stop or change the implementation of the latter now that the work on the Trans Adriatic Pipeline has started and that SNAM has become a member of it, to bring Caspian gas along that corridor via TAP (Azerbaijani gas) to take the route of European markets, also for the purposes of diversification, flexibility and security of European supplies ( 75 billion cubic meters to 2040 , with a total European energy requirement of $23 \%$ and of Italy at $36 \%$, in the face of a declining European and Italian domestic production, source IEA World Energy Outlook 2015, see also Regulation 2010/994 / EU of the European Parliament and the European Council, which establishes for each Member State the obligation to identify, through Guidelines predefined measures to ensure security of natural gas supply). All these evidences require an upgraded new "Unified European Directive for the use of subsurface and lands to produce energy/heat/resources" to produce in safety, transparency, inclusion of any scientist to study the different case histories coming from the Ministry MISE, without exclusion or disciplinary procedure, i.e., when a single out researcher exhibited an honest critical review/behavior with respect certain unsafe projects, often managed by strange enterprises located in "offshore paradise", which desire to drill with very low and "masked" capital funds, not sound for safety of citizens. Assurance tools/benefits for the researchers devoted 
to these projects, should be not reserved only to certain/few scientists - selected TOP to DOWN - but to all researchers of a research institute, that should study a certain natural gas storage site. This is the case in Italy recently: only few researchers are covered by assurance, payed by the public institutions (not payed to who is out of a project, as decided by some pro-tempore research institutions heads). A lot of evidences were collected to the public Authorities, without answers, rendering the citizens very critical to this new view of natural gas storage management (mostly if as "overpressuring"), with respect to the past, when the scientific and political managing of these infrastructures were different $[4,5]$. Charge still in the hands of public managers or professors which are responsible of this mediatic/scientific disaster should be removed, as often requested from Anticorruption Authorities too.

However, to achieve the "HUB" target through the Southern Gas Corridor - SGC - further development of interconnection infrastructure and storage capacity is required. Already now Italy has the highest degree of diversification in Europe of the routes and sources of natural gas supply (for example in the Baltic countries with a maximum of 2 sources of supply, as per maps produced with forecasts to 2022, produced by the Emergency Technical Committee and monitoring of the gas system of the Ministry MISE and of the Technical Secretariat DGMEREEN of the Ministry MISE). All this must be taken into consideration - in the new European Directive - which is the subject of this text.

It is very important to improve the communication strategies [6] to inform the local population - at a early stage of the design of the project, both for new sites or for "overpressuring" pre-existing sites. In this sense a very positive experience was performed by the author with ENEL during the recent years regarding the publication of an informative brochure for the public awareness of the population of the Romanengo area (Northern Italy), to inform what about the possible natural gas storage design (see Appendix below).

\section{CONCLUSIONS AND FUTURE PERSPECTIVE}

In Italy up to date, incentives have only been given to specific energy supply chains - above all RESs and Energy Efficiency chains - creating evident situations of conflicts of interests between politicians who legislated and "political" foundations, created by the same "environmentalistpoliticians", who typically tells to the people about "Green Economy" in public events. Therefore, this fact has "enriched" money in the pockets of some policymakers, while the $\mathrm{CO}_{2}$ in the atmosphere continued and continues to grow wherever. At that time - until the ' 90 - another important event occurred without a Unified European Directive for the use of subsurface and lands to produce energy/heat/resources" - the loss of the sense of its mission of the great national monopolies to which it was given the task of organizing the distribution of electricity and the supply and distribution of oil and gas (even the latter, in the meantime, arrived directly inside our homes, therefore in direct contact with the consumer). The Information Communication Technology (ICT) had in the meantime allowed a flexible management of energy flows and their control along the networks, making it possible to coexist more producers/sellers on the same network, segmenting the supplies and the economic matches. This started a season of the liberation of energy systems, with the protection of the consumer entrusted to virtuous competition between multiple suppliers of goods and services, rather than the "commandcontrol" operated by that same State, the owner of the monopolistic companies, which was governed by political parties. It 'been a season of great excitement and innovation that led to a much more efficient and modern system, even if it could have done much more. After great efforts also consumers, more and more "customers" and less "users" can now exercise a power of choice that will be increasingly effective thanks to the introduction of truly "smart" meters to new ICT applications. All this is profoundly changing the cultural relationships with monopolistic services imposed and lived, then, once in the past, in a totally passive way, during GHGs growth in the atmosphere. The success of RESs, which we are witnessing in recent years, is also due to this cultural revolution with the consumer who, after having learned to choose between different suppliers, is now able to conceive himself as a supplier of himself: a preliminary planning also with respect to the underground facilities, reserves, goods and resources is urgent and mandatory. Many citizens in a simple manner and populistically assimilate lmost only RESs and Energy Efficiency to the "Green Economy", without absolutely knowing anything about the real needs of raw materials or how much else about their production methods. This has led the public (who obviously pay taxes, electricity and gas bills) to approve the substantial allocations for the huge incentives on installed devices (not on the produced $\mathrm{MWh}$ ), which have become necessary for the development of renewable sources. In reality, to the electric user - the citizen - are "hidden" all the "perverse" dynamics of the incentives given only to certain sectors, characterized by a very large number of small producers (bearers of many political votes), compared to the few historical operators, who built up the socalled "large plants". These facts are "hidden" in the political programs of any party: a preliminary planning also with respect to the underground facilities, reserves, goods and resources is urgent and mandatory. The years 2015-2016 will be remembered as one of the milestones in the European transition towards a low carbon economy and in the global fight against climate change, meaning also big plant with Zero Emission devices (as $\mathrm{CCS}=\mathrm{CO}_{2}$ Capture and Storage, often "hidden" and unde-revaluated). The COP21 in Paris, the COP22 in Marrakech, the package of measures presented at the beginning of December 2016 in Bratislavia (10th Central European Energy Conference) by the European Commission have historical significance and represent the first international agreements that require the use of concrete actions for the reduction of $\mathrm{CO}_{2}$ emissions, from doors of all countries, with Europe at the forefront. In Bratislava, the European Transition Plan towards a low carbon economy and the minimization of local climate impacts was launched. This two-year period laid the foundations for the goals to be achieved by 2030. The European Commission has adopted a communication entitled "A framework Strategy for a Resilient Energy Union with a Forward-Looking-Climate Change Policy". In this context, the Regulation on the safety of gas supplies under discussion at European level is of particular importance. The regional measures - and therefore the regional energy planning - will gradually be included in the "National Emergency Plans" of the Member States involved in a chain by the event or countermeasures adopted. The inclusion in the National Plans of the regional measures would guarantee the obligatory nature. To do this, the collaboration of the national network 
managers (TSOs) and with their association, but above all the entities that search for sources and spaces in the subsurface, is essential, to say, for the eclectic operators of the subsurface, namely hydrocarbons, natural gas storage, $\mathrm{CO}_{2}$ storage, energy storage, water waste management, geothermal heat, nuclear waste management both in "near surface" sites for each country and in sound unique European "geologicalgeochemical barriers site" too [27-30], as the Italian CNENENEA school was pioneer in the studies. All it is rendering strategic and urgent a "Unified European Directive for the use of subsurface and lands to produce energy/heat/resources", herewith discussed in details.

The Paris Agreement, adopted on December, 12, 2015 at the $21^{\text {th }}$ Conference of the Parties to the Convention on Climate Change (COP21), entered into force on November, 4 , 2016, thirty days after at least 55 signing parties to the Climate Convention representing at least $55 \%$ of global GHG emissions deposited their instrument of ratification to the Secretary of the Convention. In this way, a negotiation process that originated in Durban COP17 in 2011 (Decision 1 / CP.17, Dec. 2011) was completed. The positive conclusion of such an operation was far from obvious, given that a process similar, which began in Bali in 2007, ended with the failure of the Copenhagen COP15 negotiations in 2009. The natural gas storage as well as the CO2 Storage (CCS), as well as energy storage become strategical in this scenario, mostly where the coal is considered a loser (China, India, USA, Australia etc.), creating the urgent need to plan subsurface and surface at the same time wherever, for each crustal block and for each region as well as for each country. The main Agreement is to relaunch the objective referred to in Art. 2 of the Framework Convention on Climate Change, which provides for the stabilization of the concentration of GHGs in the atmosphere at a level that prevents dangerous interference of human activities with the climate system: this is impossible without this synergic planning of the underground space and the land space together. This is impossible without a "Unified European Directive for the use of subsurface and lands to produce energy/heat/resources" to be widespread worldwide. The Agreement takes into account most of the scientific indications established by the $5^{\text {th }}$ IPCC Assessment report (Intergovernmental Panel on Climate Change): "to maintain the average temperature increase well below 2 degrees above the pre-industrial levels, recognizing that this would significantly reduce the risks and impacts of climate change". For the industrialized countries like Italy, this is an almost complete de-carbonization of the economy by 2050; this requires a radical change (paradigmatic shift) in the way of producing and consuming energy, in the way of understanding and living the cities, underground space and the territory in general, in the way of understanding the production of goods and services, especially water - revaluing completely the territories that feed the basins and the drinking water tables (not affecting them by unsafe water waste management i.e., from oil\&gas industry) - giving a special power to the politicians and managers of the natural waters basins, with respect to the use of the subsurface, recalibrating the representatives of the legislative power (votes regional clustering for the Parliaments) according to the hectares of territory represented instead that by number of inhabitants: crust/ underground space producing reserves are more important. Legislative planning, therefore, with the above mentioned new unified European Directive, such as the one proposed, must be urgent and simple, with few but clear concepts, because we are moving from a linear economy - and with " a unique permission" for the different energy supply chains by land and subsurface, that now do not speak each other and that are now managed by different authorities - to a "circular" economy, with a careful reuse of raw materials, but, above all, with a preliminary planning of harmonized and rational uses of land and subsurface to long terms uses, in the exact knowledge that the utilization of a crustal block for a single specific use can deteriorate a deep layer or a shallow layer ,compromising for a long time other uses of the crustal block, for energy production and raw materials production. In order, priority must be given to the most critical and longlasting impact (i.e. nuclear waste management) and to follow the other objectives always keeping in mind: 1) the need for increasing drinking water (the new "gold coin"); 2) the irreversibility of certain spills (e.g. water-waste management or "reactive" $\mathrm{CO}_{2}$ stored at depth). All this is the so-called "after COP21" or the politics of the territory, impossible without a unified European Directive, as the present text is proposed. In fact, the evolution of the "Paris Agreements" entirely and exclusively at this technological point in a race against time - is more necessary than ever, only with a good concerted and rational policy, where the wide-ranging scientific professional figures must prevail over populist politicians of low technological professionalism, even in the face of planetary changes such as the phenomenon of planetary changes such as the phenomenon of climate migrants, which according to the UN could, by 2050 , affect 250 million people, in addition to those that derive growing from the birth of mines - especially in Africa - for the extraction of materials necessary bacteries, namely for the so-called "Green Economy" (see also IEA Road Map 2009), instead of wells that extract fossil fuels. In February 2015, the European Commission announced its five-year strategy for the creation of a true "Energy Union" able to ensure safe, competitive and sustainable energy for Europe. Security will be achieved through the diversification of energy sources and suppliers. This is especially important for countries that have an excellent position in the geopolitical equilibrium, as is Italy, located between the Mediterranean Sea and the Adriatic Sea and therefore can become the main gateway to natural gas in Europe. Both from the sea and from the ground through LNG re-gasifiers and the future Southern Gas Corridor, which will allow the distribution in Europe of gas coming from the Caspian Sea. One also thinks of the quantities of solar energy flowing through North Africa into electricity grids on both sides of the Mediterranean. This is why some Italian cities can contribute considerably to the European agenda of "Smart Ancient Cities" such cities could play a central role in the growing network of the "Covenant of Mayors", which can really be transformed into a "Global Pact" (see Quattrocchi et al., this volume). Paradoxically, even if Italy is home to the recently inaugurated "European Interoperability Center for Electric Vehicles Grids", there has not yet been a serious study of the spaces, times and raw materials needed for this new world of electric cars from "Diffused energy" with low electrical/heat energy density $\left[\mathrm{MWh}_{\mathrm{e}} \mathrm{o}\right.$ $\mathrm{MWh}_{\mathrm{t}}$ /hectars/Year]. From this premised, clearly emerges the need for a new way of dealing with the energy planning of both cities and regions and of countries - above all the European ones - starting from revisiting and reformulating old obsolete laws and reunifying them in a single directive worldwide: the "Unified European Directive for the use of subsurface and lands to produce energy/heat/resources". 


\section{ACKNOWLEDGMENT}

The author thanks a lot Prof. Enzo Boschi to discuss daily the concepts expressed in this paper. Thank a lot to many students of University Rome 2 Tor Vergata, Dip. Engineering and most of all to Prof. Angelo Spena for the discussions on the topic. Thank you to the Set Plan Energy Enlarged Board, Ministry MIUR for the ideas and discussion at this table for many years. Thank you to Francesco Napoli, University of Rome $\mathrm{PhD}$ for the work and ideas about 3D Printers use to exhibit the productive subsurface in the exact proportions and strata/wells/unconformity, to be mentioned in the "Unified European Directive for the use of subsurface and lands to produce energy/heat/resources".

\section{REFERENCES}

[1] IEA expert Group on R\&D Priority Settings and Evaluation IEA Editor. (2012). Developments in energy education: Reducing Boundries.

[2] Quattrocchi F, Boschi E, Spena A, Buttinelli M, Cantucci B, Procesi M. (2012). Synergic and conflicting issues in planning underground use to produce energy in densely populated countries, as Italy. Subtitle: Geological storage of $\mathrm{CO}_{2}$, natural gas, geothermics and nuclear waste disposal. Applied Energy 101: 393-412. https://doi.org/10.1016/j.apenergy.2012.04.028

[3] Procesi M, Cantucci B, Buttinelli M, Armezzani G, Quattrocchi F, Boschi E. (2013). Strategic use of the underground in an energy mix plan: Synergies among $\mathrm{CO}_{2}, \mathrm{CH}_{4}$ geological storage and geothermal energy. Latium Region case study (Central Italy). Applied Energy 110: 104-131. https://doi.org/10.1016/j.apenergy.2013.03.071

[4] Quattrocchi F, Boschi E. (2015). Case histories in scientific and pseudo-scientific mass-media communication in energy/heat production from underground (geogas storage, geothermics, hydrocarbons), in the frame of Nimby Sindrome enhancement in Europe: The proposal of a new European Directive. Offshore Mediterranean Conference and Exhibition. https://doi.org/10.1186/s13567-015-0243-7

[5] Quattrocchi F, Boschi E. (2014). Case histories in scientific and pseudo-scientific mass-media communication in energy/heat production from underground (geogas storage, geothermics, hydrocarbons), in the frame of Nimby Syndrome enhancement in Europe: The proposal of a new European Directive. EGU General Assembly 2014. https://doi.org/10.1186/s13567-015-0243-7

[6] Quattrocchi F. (2008). Communication strategy for a public information campain on $\mathrm{CO}_{2}$ geological storage and on CCS as a whole: The case history in Italy from 2003 to 2008. Energy Procedia 1: 4689-4696. https://doi.org/10.1016/j.egypro.2009.02.292

[7] Quattrocchi F, Boschi E. (2015). The Commissione Ichese case history as a poor geo-ethics and communication episode in the frame of the Nimby Syndrome and geopolicy weakeness. $4^{\text {th }}$ International Conference on Earth Science \& Climate Change 6(5): 145. http://dx.doi.org/10.4172/2157-7617.S1.018

[8] Beaubien SE, Jones DG, Gal F, Barkwith AKAP, Braibant G, Baubron JC, Ciotoli G, Graziani S, Lister TR,
Lombardi S, Michel K, Quattrocchi F, Strutt MH. (2012). Monitoring of near-surface gas geochemistry at the Weyburn, Canada, $\mathrm{CO}_{2}$-EOR. International Journal of Greenhouse Gas Control 16S: S236-S262. https://doi.org/10.1016/j.ijggc.2013.01.013

[9] Cataldi R, Rendina M. (1973). Recent discovery of a new geothermal field in Italy: Alfina. Geothermics 2(3-4): 107-116. https://doi.org/10.1016/0375-6505(73)90016-3

[10] Sciarra A, Cinti D, Pizzino L, Procesi M, Voltattorni N, Mecozzi S, Quattrocchi F. (2013). Geochemistry of shallow aquifers and soil gas surveys in a feasibility study at the Rivara natural gas storage site (Po Plain, Northern Italy). Applied Geochemistry 34: 3-22. https://doi.org/10.1016/j.apgeochem.2012.11.008

[11] Quattrocchi F, Pik R, Angelone M, Barbieri M, Conti M, Guerra M, Lombardi S, Marty B, Pizzino L, Sacchi E, Scarlato P, Zuppi GM. (2000). Geochemical changes at the Bagni di Triponzo thermal spring, during the UmbriaMarche 1997-98 seismic sequence. Journal of Seismology 4: 567-587. https://doi.org/10.1023/A:1026590028678

[12] Quattrocchi F, Di Stefano G., Pizzino L, Pongetti F, Romeo G, Scarlato P, Sciacca U, Urbini G. (2000). The Geochemical Monitoring System (GMS II) prototype installed at the Acqua Difesa well (Belpasso, CT) in the etna region, addressed to seismic and volcanic surveillance: first data during the 1999 volcanic-seismic crisis. Journal of Volcanology and Geothermal Research 101(3-4): 273-306. https://doi.org/10.1016/S03770273(00)00177-3

[13] Quattrocchi F, Favara R, Capasso G, Pizzino L, Bencini R, Cinti D, Galli G, Grassa F, Francofonte S, Volpicielli G. (2003). Thermal Anomalies and fluid geochemistry framework in occurrence of the 2000-2001 NizzaMonferrato seismic sequence (Northern Italy): Episodic changes in the fault zone heat flow or chemical mixing phenomena? Natural Hazards and Earth System Sciences 3: 269-277. https://doi.org/10.5194/nhess-3-269-2003

[14] Pizzino L, Burrato P, Quattrocchi F, Valensise G. (2003). Geochemical signature of large active faults: the example of the 5 February 1783, Calabrian Earthquake. Journal of Seismology 8: 363-380. https://doi.org/10.1023/b:jose.0000038455.56343.e7

[15] Quattrocchi F, Boncio P, Pizzi A, Voltattorni A. (2012). The contribution of fluid geochemistry to define the structural pattern of the 2009 L'Aquila seismic source. Italian Journal of Geosciences 131(3): 448-458. https://doi.org/10.3301/IJG2012.31

[16] Quattrocchi F, Gallo F. (2017). If $\mathrm{CO}_{2}$ is underground in a faulted area, could around 70000 earthquakes (24 August 2016 Amatrice seismic sequence) trigger $\mathrm{CO}_{2}$ leakage at surface? Proceedings Int. Conf. TCC-9 $\left(\mathrm{CO}_{2}\right.$ Capture \& Storage), Throndeim.

[17] Salvi S, Quattrocchi F, Angelone M, Brunori CA, Billi A, Buongiorno F, Doumaz F, Funiciello R, Guerra M, Lombardi S, Mele G, Pizzino L, Salvini F. (2000). A multidisciplinary approach to earthquake research: implementation of a Geochemical Geographic Information System for the Gargano site, Southern Italy. Natural Hazards 20(1): 255-278. https://doi.org/10.1023/a:1008105621134

[18] Quattrocchi F. (1999). In search of evidences of deep fluid discharges and pore pressure evolution in the crust to explain the seismicity style of Umbria-Marche 1997- 
98 seismic sequence (Central Italy). Annals of Geophysics 42(4): 609-636. https://doi.org/10.4401/ag3743

[19] Frima C, Moretti I, Brosse E, Quattrocchi F, Pizzino L. (2005). Can diagenetic processes influence the short term hydraulic behavior evolution of a fault. Oil \& Gas Science and Technology 60(2): 213-230. https://doi.org/10.2516/ogst:2005013

[20] Buttinelli M, Procesi M, Cantucci B, Quattrocchi F. (2011). The geo-database of caprock quality and deep saline aquifers distribution for geological storage of $\mathrm{CO}_{2}$ in Italy. Energy 36: 2968-2983. https://doi.org/10.1016/j.energy.2011.02.041

[21] Improta L, Valoroso L, Piccinini D, Chiarabba C. (2015). A detailed analysis of wastewater-induced seismicity in the Val D'Agri oil field (Italy). Geophysical Research Letters 42(8):

2682-2690. https://doi.org/10.1002/2015GL063369

[22] Mancini C, Quattrocchi F, Guadoni C, Pizzino L, Porfidia B. (2000). 222Rn study throughout different seismotectonical areas: Comparison between different techniques for discrete monitoring. Annals of Geophysics 43(1): 31-60. https://doi.org/10.4401/ag3623

[23] Pizzino L, Galli G, Mancini C, Quattrocchi F, Scarlato P. (2002). Natural Gases Hazard $\left(\mathrm{CO}_{2}, 222 \mathrm{Rn}\right)$ within a quiescent volcanic region and its relations with seismotectonics: the case of the Ciampino-Marino area (Colli Albani volcano, Rome). Natural Hazards 27: 257287. https://doi.org/10.1023/a:1020398128649

[24] Girault F, Perrier F, Przylibski TA. (2016). Radon-222 and radium-226 occurrence in water: A review. https://doi.org/10.1144/sp451.3

[25] Jones DJ, Beaubien SE, Annunziatellis A, Baubron JC, Braubant G, Cardellini C, Cinti D, Davis JR, Scheib C, Lombardi S, Michel K, Morgantini N, Penner L, Quattrocchi F. (2006). Surface gas measurements and related studies for the characterization and monitoring of geological $\mathrm{CO}_{2}$ storage sites; experiences at Weyburn and in Salah. Proceedings of $\mathrm{CO}_{2} \mathrm{CS}$ International Symposium, Berkeley, California (USA) 169-172. https://doi.org/10.5194/acp-13-11839-2013

[26] Strutt MH, Baubron JC, Beaubien SE, Brach M, Cardellini C, Granieri D, Jones DG, Lombardi S, Benner LA, Quattrocchi F, Voltattorni N. (2002). Soil gas as a monitoring tool of deep geological sequestration of carbon dioxide: preliminary results from the PanCanadian EOR project in Weyburn, Saskatchewan (Canada). Greenhouse Gas Control Technologies - 6th International Conference I: 391-396. https://doi.org/10.1016/B978-008044276-1/50063-5

[27] Brookins DG. (2015). Geochemical aspects of radioactive waste disposal. United States. SpringerVerlag. https://doi.org/10.1007/978-1-4613-8254-6

[28] Ventura G, Ciabatti P. (2002). Sviluppo e applicazione di modelli di calcolo per le valutazioni di impatto ambientale di un deposito definitivo di rifiuti radioattivi a bassa attività. Rapporto Interno ENEA-GSP3Hydrocontrol S.r.l Cagliari.
[29] Ventura G. (2003). Sistema Informativo Geografico per il sito del Deposito Nazionale dei Materiali Radioattivi. $\begin{array}{lll}\text { ENEA GSP3 SITO. } & \end{array}$ http://www.archivionucleare.com/files/studio-gsp3-sitodeposito-nazionale-2003.pdf.

[30] Perel'man AI. (1986). Geochemical barriers: Theory and practical applications. Applied Geochemistry 1: 669-680. https://doi.org/10.1016/0883-2927(86)90088-0

\section{APPENDIX}

Informative Brochure realized by INGV and ENEL to inform the population about the possible natural gas storage project. The dialog was very positive.
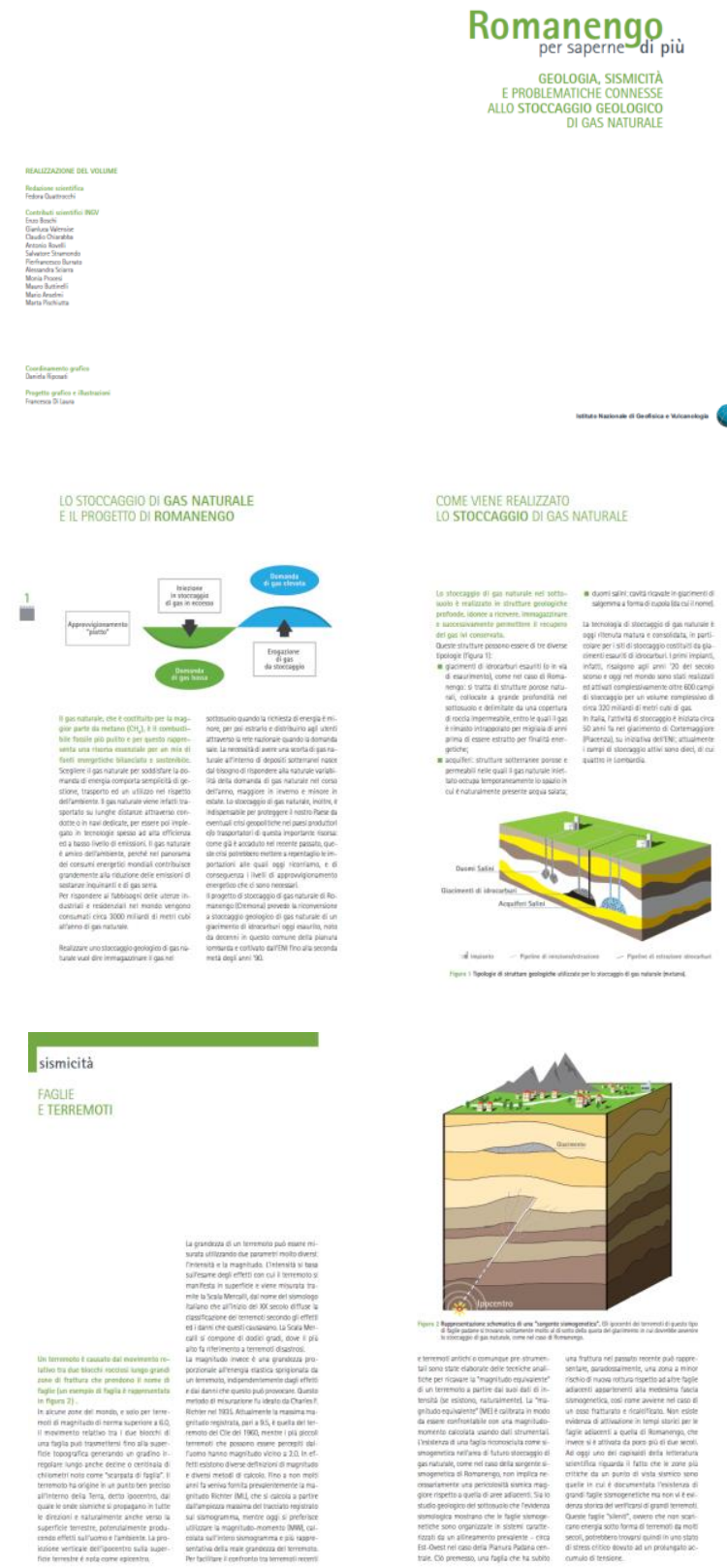